\title{
Macrocheles muscaedomesticae (Acari, Macrochelidae) and a species of Uroseius (Acari, Polyaspididae) phoretic on Musca domestica (Diptera, Muscidae): effects on dispersal and colonization of poultry manure
}

\author{
Tatyana Sacchi Carmona Rodrigueiro \& Angelo Pires do Prado
}

\author{
Depto de Parasitologia, Instituto de Biologia, Universidade Estadual de Campinas, Caixa Postal 6109, 13083-970, Campinas, SP, \\ Brasil. (tatyscr@bol.com.br; apprado@obelix.unicamp.br)
}

\begin{abstract}
Differences in the phoresy of the mites Macrocheles muscaedomesticae (Scopoli, 1972) (Macrochelidae) and Uroseius sp. (Polyaspidae) on the house fly, Musca domestica (Linnaeus, 1758) and the similarities in their phoretic dispersal and parasitism are discussed, altogether with the effects on predator-prey interactions. The prevalence and intensity of phoresy in the mite species were significantly related to the attachment site on the hosts. The phoresy of Uroseius sp. was correlated with temperature but not with rainfall and relative humidity. Selective pressure in the environment resulted in displacement and the emergence of local and regional populations. These results suggest that in each habitat the populations will use different resources and will show several relationships with other species, as well as a selection for morphological and behavioral types.
\end{abstract}

KEYWORDS. Dispersal, house flies, mites, phoresy, poultry manure.

\section{INTRODUCTION}

Phoresy is a phenomenon in which an animal (the phoretic stage or phoront) actively seeks and attaches to the surface of another animal and than enters quiescence (no ontogenesis or feeding) in order to be transported to other habitats. After migration, if the conditions are suitable, the phoretics leave the host to colonize a new habitat. This dispersal is vital for species that live in fragmented areas separated by distances that are unsurpassable to them (FARISH \& AXTELL, 1971; BINNS, 1982; Athias-Binche \& MoRAnd, 1993; KaliszewsKi $e t$ al., 1995).

Most free-living mites live in discontinuous and transient habitats. When the food in these habitats finishes, the mites move to a new source. Most mites discover their food through active or passive dispersal, and the area that they are able to explore is a function of the distance they have to travel and the duration of the journey. Mites have a restricted range because of their limited ability to disperse and their restricted environmental tolerance. As a result, several mechanisms of dispersal are used in different stages of development. Mites reproduce continuously in a suitable environment but disperse when some environmental factor adversely affects their presence in the habitat. This dispersal can be irregular or seasonal. The adaptations for dispersal can be evaluated based on the survival of the mites and indicate the direction and intensity of natural selection. The specialization of dispersal behavior reveals the variability that contributes to the distribution and diversity of mites (Mitchell, 1970).

Recognition of the ideal host is fundamental for transportation to a new site, and is often based on chemical or olfactory stimuli produced by the host. Macrocheles muscaedomesticae (Scopoli, 1972) (Macrochelidae) is attracted to its host (beetles or houseflies) by water-soluble compounds on the host cuticle that are produced or accumulated by the host. Olfactory receptors on tarsi I enable phoretic Gamasida to locate their hosts while receptors on the palpi are involved in locating and attaching to the host and in perception of the substrate during movement (FARISH \& Axtell, 1966; Wicht et al., 1971; CoONs \& Axtell, 1973; HunTER \& Rosario, 1988).

The peculiarities of phoresy include the active seeking of a host, the recognition of signs for attachment and specificity for a host, quiescence, recognition of the signs to abandon the host and, if necessary, synchrony with the host life cycle. Some of these responses are analogous to those seen in parasites, particularly the attraction to hosts and the synchrony with their life cycles (KALISZEWSKi et al., 1995).

Phoresy may be an adaptation to survival, or may be parasitic, since it involves displacement through interactions in ecosystems. Environmental variations, with their effect on intra and interspecific relationships, lead to displacement and persistence in different habitats. The difficulty in defining phoresy reflects the diversity of behavioral and ecological parameters of the species involved. Phoresy is important for maintaining species that can act as predators or parasites in different development stages, and serves to define the survival strategy of mutualistic, predatory and parasitic species.

The aim was examined the phoresy of two species of Gamasida mites, M. muscaedomesticae and Uroseius sp. (Polyaspidae), their potential to control Musca domestica (Linnaeus, 1758), and also their influence to the colonization of poultry manure.

\section{MATERIAL AND METHODS}

Flies were collected in caged poultry houses on a poultry farm in Santa Cruz da Conceição, State of São 
Paulo, southeastern Brazil (1959.5'S 49 ${ }^{\circ} 23.5^{\prime} \mathrm{W}$ ), from July 2001 to August 2002. The poultry house was the "narrow-house" type, with open sides and one row of cages on each side of a central concrete aisle $(60 \mathrm{~m} \times 5 \mathrm{~m})$. Adult flies were trapped around the poultry house and near the manure pile using the sweep method, then placed in breeding cages and transported to the Entomology Laboratory at Universidade Estadual de Campinas, State of São Paulo. In the laboratory, the material collected was frozen and the houseflies were separated. The flies were then placed in a plastic container with absorbent paper and dried at $40^{\circ} \mathrm{C}$ to prevent their deterioration and to keep the mites attached to the flies. The number and sex of the flies, the number of mites per fly and their sites of attachment to the host flies were determined. The sites included the head (HD), mouthparts (MP), thorax (TR), abdomen ( $\mathrm{AB}$ ), legs (LG), wings (WG), head-thorax implant (HD-TR) and thorax-abdomen implant (TR-AB).

Based on the concepts of MARGolis et al. (1982) and Bush et al. (1997), the prevalence of phoresy was defined as the number of phoretic individuals (of both species and of each species separately) on host flies divided by the number of flies examined and grouped according to the attachment site and the sex of the host flies. The intensity of phoresy was defined as the number of phoretic mites per host fly in a sample (the number of individuals in an infrapopulation), grouped according to attachment site and the sex of the host flies. The frequency of phoresy ("density") was defined as the number of individuals of a particular phoretic species in a sample obtained and they were grouped according to attachment site and the sex of the host flies. Prevalence, intensity and frequency were considered quantitative descriptors of the phoretic mite populations and were associated with qualitative descriptors such as the attachment sites and the sex of the host flies.

The local climatic data (temperature, relative humidity and rainfall) were obtained monthly from the Academia da Força Aérea de Pirassununga, State of São Paulo.

Although raw means were plotted for examination, statistical analysis were done with transformed data $\left[\log _{10}(\mathrm{n}+1)\right]$ to normalize variances. Analysis of variance (ANOVA) followed by the Duncan test (PROC GLM) was used to compare the prevalence, intensity and frequency of phoresy according to season (spring, summer, fall, winter); sex of the fly populations sampled; sex of the host flies infected with phoretic mites; attachment sites on host flies and phoretic mite species. The relationships between phoresy (prevalence and intensity), the fly population sampled, the sex of the host flies sampled and local meteorological variables were examined using Pearson correlation analysis (PROC CORR). A significance level of $\alpha=0.05$ was used in all analysis. The statistical comparisons were done using the program SAS System for Windows, version 6.12. (S.A.S. User's guide: Statistics, SAS Institute, Inc., Cary, North Carolina, USA 1996).

The specimens of mites and flies were deposited in the Museu de História Natural "Adão Cardoso" at Instituto de Biologia, Universidade Estadual de Campinas, State of São Paulo.

\section{RESULTS AND DISCUSSION}

Phoresy can be considered a dispersal strategy that can lead to parasitism because of the phylogenetic specificity of the interaction and the synchrony with the host life cycle. An increase in the abundance of phoretic mites results in a regulation of their numbers in order to avoid damage to the host, particularly the ability to fly, which is critical to the migratory success of mites (AtHIASBINCHE \& MORAND, 1993; KALISZEWSKI et al., 1995).

The phoretic mite species studied were adult females of M. muscaedomesticae and Uroseius sp. deutonymphs, as defined by Krantz $(1962,1978)$ and KRANTZ \& AinsCOUGH (1990). The prevalence of phoresy was significant $(\mathrm{p}<0.05)(\mathrm{F}=4.76 ; \mathrm{p}<0.0001)$, for season $(\mathrm{F}=6.68 ; \mathrm{p}<0.0001)$ and attachment site $(\mathrm{F}=5.15$; $\mathrm{p}<0.0001)$. The frequency of phoresy was significant $(\mathrm{F}=5.24 ; \mathrm{p}<0.0001)$ for season $(\mathrm{F}=4.85 ; \mathrm{p}<0.0028)$; sex of the fly population $(\mathrm{F}=4.79 ; \mathrm{p}<0.0297)$ and attachment site $(F=6.47 ; p<0.0001)$. The intensity of phoresy was significant $(\mathrm{F}=5.48 ; \mathrm{p}<0.0001)$ for attachment site $(\mathrm{F}=3.98 ; \mathrm{p}<0.0007)$ and phoretic species $(\mathrm{F}=8.18$; $\mathrm{p}<0.0047)$ (tab. I).

Phoretic species may be attracted to a particular host because of the similarity in their ecological niches and may use tactile and olfactory stimuli to localize their food resource and host transport. The ability of mites to localize their hosts, attach to them, and then leave them upon reaching new habitats is important for an equilibrium

Table I. The mean of prevalence, frequency and intensity of phoresy on Musca domestica in relation to the season, fly population and sex of the flies, attachment site on the flies, and species of phoretic mites. For each factor (Season, Sex FP, sites, Sex HF, Species), the means in a column followed by different letters are significantly different (ANOVA followed by the Duncan test, $\alpha=0.05$ ) (Prev-Mt, prevalence of phoretic mites; Freq-Mt, frequency of phoretic mites; Int-Mt, intensity of phoretic mites; MAC, M. muscaedomesticae (adult females); URO, Uroseius sp. (deutonymphs); AB, abdomen; MP, mouthparts; WG, wing implant; HD, head; HD-TR, head-thorax implant; TR, thorax; TR-AB, thorax-abdomen implant; LG, legs (pairs I, II or III); Sex FP, sex of the fly population sampled; Sex HF, sex of the host flies infected with phoretic mites).

\begin{tabular}{|c|c|c|c|c|}
\hline & & Prev-Mt & Freq-Mt & Int-Mt \\
\hline \multirow[t]{4}{*}{ Season } & Spring & $0.0093 \mathrm{a}$ & $3.2222 \mathrm{a}$ & $0.6243 a$ \\
\hline & Summer & $0.0059 \mathrm{ab}$ & $1.4412 \mathrm{~b}$ & $0.6039 a$ \\
\hline & Fall & $0.0034 \mathrm{~b}$ & $0.6389 b$ & $0.5000 \mathrm{a}$ \\
\hline & Winter & $0.0035 b$ & $1.8500 \mathrm{~b}$ & $0.6056 \mathrm{a}$ \\
\hline \multirow[t]{2}{*}{ Sex FP } & 0 & $0.0041 \mathrm{a}$ & $1.3152 \mathrm{~b}$ & $0.5852 \mathrm{a}$ \\
\hline & $\varsubsetneqq$ & $0.0062 \mathrm{a}$ & $2.3485 \mathrm{a}$ & $0.6065 \mathrm{a}$ \\
\hline \multirow[t]{8}{*}{ Sites } & $\mathrm{AB}$ & $0.0107 \mathrm{a}$ & $4.162 \mathrm{a}$ & $0.8333 \mathrm{a}$ \\
\hline & MP & $0.0027 \mathrm{ab}$ & $0.722 \mathrm{ab}$ & $0.5556 \mathrm{ab}$ \\
\hline & WG & $0.0022 \mathrm{ab}$ & $1.500 \mathrm{ab}$ & $0.5000 \mathrm{ab}$ \\
\hline & HD & $0.0066 \mathrm{ab}$ & $1.500 \mathrm{ab}$ & $0.6798 \mathrm{a}$ \\
\hline & HD-TR & $0.0035 \mathrm{ab}$ & $1.077 \mathrm{ab}$ & $0.6282 \mathrm{a}$ \\
\hline & $\mathrm{TR}$ & $0.0021 \mathrm{ab}$ & $0.850 \mathrm{ab}$ & $0.5583 \mathrm{ab}$ \\
\hline & TR-AB & $0.0016 \mathrm{~b}$ & $0.625 \mathrm{ab}$ & $0.5000 \mathrm{ab}$ \\
\hline & LG & $0.0032 \mathrm{ab}$ & $0.932 \mathrm{ab}$ & $0.5152 \mathrm{ab}$ \\
\hline \multirow[t]{2}{*}{ Sex HF } & $\sigma$ & $0.0039 a$ & $1.3718 \mathrm{a}$ & $0.5995 \mathrm{a}$ \\
\hline & $\varsubsetneqq$ & $0.0060 \mathrm{a}$ & $2.2192 \mathrm{a}$ & $0.5974 \mathrm{a}$ \\
\hline \multirow[t]{2}{*}{ Species } & MAC & $0.0035 \mathrm{a}$ & $2.0541 \mathrm{a}$ & $0.7139 a$ \\
\hline & URO & $0.0032 \mathrm{a}$ & $1.7965 \mathrm{a}$ & $0.4845 b$ \\
\hline
\end{tabular}


between attractive flies and fresh manure (FARISH \& AXTELL, 1966).

In Gamasina (Macrochelidae and Parasitidae) and Uropodina, which use phoretic displacement, the host aids dispersion when there is some similarity between the habitats of the phoretic mites and the host. Phoresy generally declines with increasing substrate age (BINNS, 1982).

Poultry houses represent an artificial environment in which there is an accumulation of organic matter that contributes to fly development. The equilibrium of the management of manure and biological control could be suggested because of the movement of predator mites and dispersal behavior that occur on common species in this habitat, meaning that $M$. muscaedomesticae and Uroseius sp. are phoretic on house flies, which could be their food resource and thus may migrate on their preys (the house flies).

The prevalence of phoresy for $M$. muscaedomesticae was significant $(\mathrm{F}=5.54 ; \mathrm{p}<0.0001)$ for season $(\mathrm{F}=5.39 ; \mathrm{p}<0.0018)$; sex of the fly population $(\mathrm{F}=14.38$; $\mathrm{p}<0.0003)$ and attachment site $(\mathrm{F}=5.04 ; \mathrm{p}<0.0001)$. The frequency of phoresy for $M$. muscaedomesticae was significant $(\mathrm{F}=3.83 ; \mathrm{p}<0.0001)$ for sex of the fly population $(\mathrm{F}=12.52 ; \mathrm{p}<0.0006)$; sex of the host flies $(\mathrm{F}=9.87 ; \mathrm{p}<$ $0.0022)$ and attachment site $(\mathrm{F}=4.18 ; \mathrm{p}<0.0003)$. The intensity of phoresy for $M$. muscaedomesticae was significant $(\mathrm{F}=5.45 ; \mathrm{p}<0.001)$ for season $(\mathrm{F}=9.03 ; \mathrm{p}<$ $0.0001)$; sex of the fly population $(\mathrm{F}=9.64 ; \mathrm{p}<0.0025)$ and attachment site $(\mathrm{F}=4.01 ; \mathrm{p}<0.0007)$ (tab. II).

The prevalence of phoresy for deutonymphs of Uroseius sp. was significant $(\mathrm{F}=2.98 ; \mathrm{p}<0.001)$ for season $(\mathrm{F}=6.47 ; \mathrm{p}<0.0005)$ and attachment site $(\mathrm{F}=2.20$; $\mathrm{P}<0.0336)$. The frequency of phoresy was significant $(F=3.16 ; p<0.0005)$ for season $(F=5.63 ; p<0.0013)$ and attachment site $(F=2.88 ; \mathrm{p}<0.0063)$. The intensity of phoresy for Uroseius sp.was significant $(\mathrm{F}=5.42$; $\mathrm{p}<0.0001)$ for season $(\mathrm{F}=12.05 ; \mathrm{p}<0.0001)$; sex of the fly population $(\mathrm{F}=5.57 ; \mathrm{p}<0.0204)$ and attachment site $(\mathrm{F}=3.33 ; \mathrm{p}<0.0033)(\mathrm{tab} . \mathrm{II})$.

The prevalence of phoresy by the mites $M$. muscaedomesticae and Uroseius sp. was seasonal, probably because meteorological variables influenced the population size. Thus, the low fly population seen in the autumn and in May most likely reflected the use of insecticides and the occurrence of low temperatures during these periods.

The prevalence and intensity of infestation by phoretic mites can affect the host performance and suggest that there is a regulatory effect of the mites on the flies. The overall distribution of mites and the host density regulate the density of mites by affecting their mortality and ability to disperse. Flies with the heaviest mite burdens would be least successful in colonizing a new habitat, and those mites associated with unsuccessful flies would be eliminated from the population. Reducing the mites per fly probably contributes to the stability and coexistence of species as in the case of the Macrocheles-Drosophila interaction (PolAK, 1996).

The longevity and fertility of Dermatobia hominis (Linnaeus Jr, 1781) are not affected by phoresy of $M$. muscaedomesticae even though the mites use these flies as a vector. Copulatory behavior in D. hominis may be adversely affected by the large number of mites usually present around the genitalia of these flies. Dermatobia hominis would therefore be contaminated with phoretic mites if the larvae pupated in places with a high content of organic matter and manure because in these habitats, we can find $M$. muscaedomesticae and other species of

Table II. The mean prevalence, frequency and intensity of phoresy for each mite species on $M$. domestica in relation to the season, fly population and sex of the flies, and attachment site on the flies. For each factor (Season, Sex FP, sites, Sex HF, Species), the means in a column followed by different letters are significantly different (ANOVA followed by the Duncan test, $\alpha=0.05$ ) (Prev-Mt, prevalence of phoretic mites; Freq-Mt, frequency of phoretic mites; Int-Mt, intensity of phoretic mites; MAC, M. muscaedomesticae (adult females); URO, Uroseius sp. (deutonymphs); AB, abdomen; MP, mouthparts; WG, wing implant; HD, head; HD-TR, headthorax implant; TR, thorax; TR-AB, thorax-abdomen implant; LG, legs (pairs I, II or III); Sex FP, sex of the fly population sampled; Sex HF, sex of the host flies infected with phoretic mites).

\begin{tabular}{|c|c|c|c|c|c|c|c|}
\hline & & \multicolumn{2}{|c|}{ Prevalence } & \multicolumn{2}{|c|}{ Frequency } & \multicolumn{2}{|l|}{ Intensity } \\
\hline & & MAC & URO & MAC & URO & MAC & URO \\
\hline \multirow{4}{*}{ Season } & Spring & $0.0044 \mathrm{ab}$ & $0.0086 \mathrm{a}$ & $2.5185 \mathrm{a}$ & $3.926 a$ & $0.4140 \mathrm{c}$ & $0.8345 a$ \\
\hline & Summer & $0.0068 \mathrm{a}$ & $0.0007 \mathrm{~b}$ & $2.6471 \mathrm{a}$ & $0.235 b$ & $1.1196 \mathrm{a}$ & $0.0882 \mathrm{c}$ \\
\hline & Fall & $0.0026 b$ & $0.0008 b$ & $1.1667 \mathrm{a}$ & $0.111 b$ & $0.9167 \mathrm{ab}$ & $0.0833 \mathrm{c}$ \\
\hline & Winter & $0.0022 b$ & $0.0021 b$ & $1.9184 \mathrm{a}$ & $1.784 b$ & $0.6889 \mathrm{bc}$ & $0.5257 b$ \\
\hline \multirow[t]{2}{*}{ Sex FP } & $\sigma$ & $0.0016 b$ & $0.0031 \mathrm{a}$ & $0.8667 \mathrm{~b}$ & $1.7447 \mathrm{a}$ & $0.5526 b$ & $0.6163 a$ \\
\hline & $\subsetneq$ & $0.0048 \mathrm{a}$ & $0.0033 \mathrm{a}$ & $2.8636 \mathrm{a}$ & $1.8333 \mathrm{a}$ & $0.8172 \mathrm{a}$ & $0.3958 b$ \\
\hline \multirow[t]{8}{*}{ Sites } & $\mathrm{AB}$ & $0.0069 \mathrm{a}$ & $0.0075 \mathrm{a}$ & $4.216 \mathrm{a}$ & $4.108 \mathrm{a}$ & $1.2564 \mathrm{a}$ & $1.0000 \mathrm{a}$ \\
\hline & MP & $0.0017 \mathrm{ab}$ & $0.0011 \mathrm{a}$ & $0.889 \mathrm{ab}$ & $0.556 \mathrm{ab}$ & $0.7778 \mathrm{ab}$ & $0.3333 \mathrm{abc}$ \\
\hline & WG & $0.0000 \mathrm{~b}$ & $0.0022 \mathrm{a}$ & $0.000 \mathrm{~b}$ & $3.000 \mathrm{a}$ & $0.000 \mathrm{c}$ & $1.0000 \mathrm{a}$ \\
\hline & $\mathrm{HD}$ & $0.0068 \mathrm{a}$ & $0.0029 a$ & $2.000 \mathrm{a}$ & $1.000 \mathrm{a}$ & $0.6667 \mathrm{abc}$ & $0.6286 \mathrm{abc}$ \\
\hline & HD-TR & $0.0048 \mathrm{ab}$ & $0.0000 \mathrm{~b}$ & $2.154 \mathrm{a}$ & $0.000 \mathrm{~b}$ & $0.7310 \mathrm{abc}$ & $0.0000 \mathrm{c}$ \\
\hline & $\mathrm{TR}$ & $0.0018 \mathrm{ab}$ & $0.0005 \mathrm{ab}$ & $1.100 \mathrm{a}$ & $0.600 \mathrm{ab}$ & $0.8687 \mathrm{ab}$ & $0.2500 \mathrm{bc}$ \\
\hline & TR-AB & $0.0012 \mathrm{ab}$ & $0.0003 \mathrm{ab}$ & $1.000 \mathrm{a}$ & $0.250 \mathrm{ab}$ & $0.7500 \mathrm{abc}$ & $0.2500 \mathrm{bc}$ \\
\hline & LG & $0.0006 b$ & $0.0027 \mathrm{a}$ & $0.429 a b$ & $1.391 \mathrm{a}$ & $0.2765 b c$ & $0.7428 \mathrm{ab}$ \\
\hline \multirow[t]{2}{*}{ Sex HF } & $\sigma$ & $0.0017 \mathrm{a}$ & $0.0030 \mathrm{a}$ & $0.9737 b$ & $1.7692 \mathrm{a}$ & $0.6017 \mathrm{a}$ & $0.5974 \mathrm{a}$ \\
\hline & $\varsubsetneqq$ & $0.0044 \mathrm{a}$ & $0.0033 \mathrm{a}$ & $2.6164 a$ & $1.8219 \mathrm{a}$ & $0.7687 \mathrm{a}$ & $0.4262 \mathrm{a}$ \\
\hline
\end{tabular}


phoretic mites (MoYA, 1981).

As with M. muscaedomesticae, the Uroseius sp. nymphs showed a significant correlation with the attachment sites on the hosts and this was related to their success in colonizing a new habitat. Whereas the implant sites (HD-TR and TR-AB) were more attractive to M. muscaedomesticae, the wings and head were more attractive to Uroseius sp. nymphs, while the abdomen was attractive to both. These ecological and behavioral differences enhance success in the colonization of new habitats.

The intensity of phoresy of $M$. muscaedomesticae on female house flies may be related to oviposition by the latter during the colonization of fresh manure. Uroseius sp. was not attracted to flies that were looking for new oviposition sites on fresh manure, thus indicating that this species probably had little effect in controlling house flies compared with M. muscaedomesticae.

Correlation analysis indicated a negative relationship between the frequency of phoresy on the fly population and meteorological variables. The intensity and frequency of phoresy by Uroseius sp. were negatively related to temperature and relative humidity $(\mathrm{p}<0.05)$, whereas the prevalence, frequency and intensity of phoresy by $M$. muscaedomesticae were positively correlated with meteorological variables (tab. III).

Manure can be considered a homogeneous habitat with abundant resources for breeding and development of various arthropod species. Environmental heterogeneity may occur through climatic variations in temperature and relative humidity, as well as through the removal of manure and treatment with insecticides. The

Table III. Pearson correlation analysis $(\alpha=0.05)$ between the frequency, prevalence and intensity of phoresy for the two mite species (M. muscaedomesticae and Uroseius sp.) and several meteorological variables (Rfm, mean monthly rainfall; $\mathrm{Hm}$, mean monthly relative humidity; Tm, mean monthly temperature; FreqFP, frequency of fly population; FreqHF, frequency of host flies sampled; FrMac, frequency of M. muscaedomesticae; FrUro, frequency of Uroseius sp.; Prev, prevalence of phoretic mites; IntMac, intensity of M. muscaedomesticae; IntUro, intensity of Uroseius sp.).

\begin{tabular}{llccc}
\hline & & $\mathrm{Rfm}$ & $\mathrm{Hm}$ & $\mathrm{T} \mathrm{m}$ \\
\hline FreqFP & $\mathrm{r}$ & -0.2977 & -0.4639 & -0.3581 \\
& $\mathrm{p}<$ & 0.0014 & 0.0001 & 0.0001 \\
\hline FreqHF & $\mathrm{r}$ & 0.0609 & 0.0062 & 0.0097 \\
& $\mathrm{p}<$ & 0.5230 & 0.9477 & 0.9184 \\
\hline FrMac & $\mathrm{r}$ & 0.09364 & 0.0735 & 0.06326 \\
& $\mathrm{p}<$ & 0.3261 & 0.4409 & 0.5076 \\
\hline FrUro & $\mathrm{r}$ & 0.0090 & -0.0246 & -0.0092 \\
& $\mathrm{p}<$ & 0.9250 & 0.7962 & 0.9228 \\
\hline Prev & $\mathrm{r}$ & 0.2088 & 0.1869 & 0.1420 \\
& $\mathrm{p}<$ & 0.0271 & 0.0485 & 0.1352 \\
\hline IntMac & $\mathrm{r}$ & 0.1650 & 0.1229 & 0.1892 \\
& $\mathrm{p}<$ & 0.0910 & 0.2092 & 0.0521 \\
\hline IntUro & $\mathrm{r}$ & -0.1385 & -0.1463 & -0.2193 \\
& $\mathrm{p}<$ & 0.1567 & 0.1344 & 0.0239 \\
\hline T m & $\mathrm{r}$ & 0.4897 & 0.5262 & \\
& $\mathrm{p}<$ & 0.0001 & 0.0001 & \\
\hline
\end{tabular}

loss of resources leads to dispersal and the exploration of different niches to maintain the existence of species within the community.

The phoresy of mites and the house fly predation rates seen here were comparable with those reported for mite species of the genus Iponemus Lindquist, 1969 that parasitize the eggs of coleopteran hosts, the females of which carry the phoretic mites. The mite nymphs travel with these coleopterans and leave the host during oviposition to parasitize the eggs, where they remain until mating. The mites mature in colonies of coleopterans where they have a high probability of finding food and hosts. However, destructive behavior of these mites can reduce the coleopteran host density and adversely affect mite dispersal. Each successive reduction makes it more difficult to find a new host and increases the selection pressure against the phoretic mites, with a tendency for them to parasitize a greater number of coleopteran host eggs (MitChell, 1970).

The results showed that there was a preference by the mites for the abdominal region and for females. We suggest that the success of phoresy is determined by an assemblage of factors, including habitat similarity, which favor the development of fly eggs and of predator phoretic mites, particularly since phoresy itself does not affect carrier displacement and thus the success of phoretic mites. The differences between attachment sites would reflect an association between attachment behavior and protection during the displacement for each mites species. Macrocheles muscaedomesticae attaches by the chelicerae whereas Uroseius sp. attaches by an anal pedicel. The fragility of attachment may depend on the site used and on movements by the host fly. The number of mites per fly would be influenced by the survival and fitness of flies. Thus, a low number of mites per fly would be advantageous in a new habitat because host displacement would not be adversely affected.

Migrations maintain the gene flow among mites in poultry house populations, which can eventually become homogeneous because of the abundance and constancy of available resources. However, local disturbances, such as the removal of manure and/or the use of insecticides, can lead to species displacement between manure piles and poultry houses. Such changes in environmental conditions promote dispersion of the mite species to other regions with new habitats and new possibilities for colonization.

\section{REFERENCES}

Athias-Binche, F. \& Morand, S. 1993. From phoresy to parasitism: the examples of mites and nematodes. Research and Reviews in Parasitology, Valencia, 53:73-79.

Binns, E. S. 1982. Phoresy as migration: some functions and aspects of phoresy in mites. Biological Review, Mainz, 57:571-620,

Bush, A. O.; Lafferty, K. D. et al. 1997. Parasitology meets ecology on its own terms: Margolis et al. revisited. Journal of Parasitology, Winston-Salem, 83(4):575583.

Coons, L. B. \& Axtell, R. C. 1973. Sensory setae of the first tarsi and palps of the mites Macrocheles muscaedomesticae (Acarina: Macrochelidae). Annals of the Entomological Society of America, Lanham, 66(3): 539-544. 
Farish, D. J. \& Axtell, R. C. 1966. Sensory function of the palps and first tarsi of Macrocheles muscaedomesticae (Acarina: Macrochelidae), a predator of house fly. Annals of the Entomological Society of America, Lanham, 59:165-170.

__. 1971. Phoresy redefined and examined in Macrocheles muscaedomesticae (Acarina: Macrochelidae). Acarologia, Paris, 13:16-25.

Hunter, P. E. \& Rosario, R. M. T. 1988. Associations of Mesostigmata with other arthropods. Annual Review of Entomology, Palo Alto, 33:393-417.

Kaliszewski, M.; Athias-Binche, F. \& Lindquist, E. E. 1995. Parasitism and parasitoidism in Tarsonemina (Acari: Heterostigmata) and evolutionary considerations. Advances in Parasitology, London, 35:335-367.

KrantZ, G. W. 1962. A review of the genera of the family Macrochelidae Vitzthum, 1930 (Acarina: Mesostigmata). Acarologia, Paris, 4:143-173.

_. 1978. A manual of acarology. Oregon, Oregon University. 509 p.
Krantz, G. W. \& Ainscough, B. D. 1990. Acarina: Mesostigmata (Gamasida). In: Dindal, D. L. Soil biology guide. New York, John Wiley \& Sons. 583-665p.

Margolis, L.; Esch, G. W. et al. 1982. The use of ecological terms in parasitology (Report of an ad hoc Committee of the American Society of Parasitologists). Journal of Parasitology, Winston-Salem, 68(1):131-133.

Mitchell, R. 1970. An analysis of dispersal in mites. American Naturalist, Chicago, 104(939):425-431.

MoyA, B. G. E. 1981. Effects of Macrocheles muscaedomesticae (Scopoli) on the sexual behavior and longevity of Dermatobia hominis (L. Jr.). Revista Brasileira de Biologia, Rio de Janeiro, 41(2):237-241.

POLAK, M. 1996. Ectoparasitic effects on host survival and reproduction: the Drosophila-Macrocheles association. Ecology, Washington, 77(5):1379-1389.

Wicht, M. C., JR.; Rodriguez, J. G. et al. 1971. Attractant to Macrocheles muscaedomesticae (Acarina) present in house fly, Musca domestica. Journal of Insect Physiology, Columbus, 17:63-67. 